\title{
TOXIC EFFECT STUDY OF BACILLUS THURINGIENSIS (B.T.) ISOLATE AND ARTEMISIA JUDAICA L., PLANT EXTRACT AGAINST POTATO TUBER MOTH, PHTHORIMAEA OPERCULELLA (ZELLER) (LEPIDOPTERA: GELECHIIDAE)
}

\author{
Iman I. Imam ${ }^{1 *}$ and Usama M. Abu El Ghiet ${ }^{2}$ \\ ${ }^{1}$ Economic Entomology Unit, Department of Plant Protection, Desert \\ Research Center, El-Matareya, Cairo, Egypt \\ ${ }^{2}$ Economic Entomology Unit, Department of Plant Protection, Desert \\ Research Center, and Biological Department, Faculty of Science, \\ Jazan University, KSA \\ *E-mail: imann_7298@yahoo.com
}

\begin{abstract}
D otato tuber moth (PTM), Phthorimaea operculella 1 (Lepidoptera: Gelechiidae) is one of the serious worldwide pest of potato (Solanum tuberosum L. Solanaceae). This pest by making irregular tunnels leaves excreta behind and led to a considerable yield loss. Trials were conducted to evaluate the effect of Bacillus thuringiensis isolate against newly emerged larvae of PTM. It had been found that the total larval death recorded 14 and $58 \%$ of larval death at 1.25 and $10 \mathrm{CFU} / \mathrm{ml}$, respectively. The potential of extract of Artemisia judaica against PTM larvae showed increase in larval mortality from 34 to $76 \%$ at 125 to $1000 \mathrm{ppm}$, respectively. In this study, the effect of Artemisia judaica extract on Phthorimaea operculella larval instar was more effective than the effect of Bacillus thuringiensis isolate. In order to get the best results when using two bio-control agents in IPM strategies, bacteria should be used first and then the plant extract.
\end{abstract}

Keywords: Bacillus thuringiensis, Artemisia judaica, Phthorimaea operculella, biological control agents

Bacterial infections in insects can be broadly classified as bacteremia, septicemia, and toxemia. Bacteremia occurs when the bacteria multiply in the insect's hemolymph without the production of toxins. This situation occurs in the case of bacterial symbionts and rarely occurs with bacterial pathogens (Durasula et al., 1997). Septicemia occurs most frequently with pathogenic bacteria, which invade the hemocoel, multiply, produce toxins, and kill the insect (Wang et al., 1993). Toxemia occurs when the bacteria are confined to the gut lumen and produce toxins (Garczynski and Endo, 1991). The spore forming bacilli have received the most attention as biological control agents. 
Many of them produce proteinaceous insect selective protoxins during sporulation. One member, Bacillus thuringiensis, has been used as a microbial pesticide against several insect pests, particularly lepidopterans. $B$. thuringiensis is a gram-positive spore forming bacterium that produces a parasporal crystal protein inclusion during its sporulation. B. thuringiensis has become the leading biopesticide since the beginning of the 1960s. The toxicology of $B$. thuringiensis is complex and its potency against particular insects varies with the strain of $B$. thuringiensis used.

Several studies were conducted in this area, Haghighian et al. (2008) and Hasheminia et al. (2011), mentioned that, the insecticidal effects of Artemisia judaica L. extract containing growth retardation, antifeedant, and larvicidal effects. Khosravi and Sendi (2013) observed that $A$. judaica extract affected the nutritional indices and also showed antifeedant activities on Glyphodes pyloalis Walker. Anshul et al. (2015) showed that methanolic extract of powdered $A$. judaica leaves adversely affect Helicoverpa armigera. The extract affected larvae by inhibition and disruption of the growth, development and histopathological and biological parameters of $H$. armigera. The essential oil of $A$. judaica has been demonstrated to possess insecticidal activity and repellence against several insects, such as Callosobruchus maculatus (Fab.) and Sitophilus oryzae L. (Aggarwal et al., 2001 and AbdElhady, 2012). Many studies reported that plants are considered as one of the richest sources that can be used as pest control agents (Nakatani et al., 2002). In Egypt, some attempts have been done to monitor insecticidal activity of different plant extracts against many insects (Farag, 2002 and Sadek, 2003).

Potato tuber moth (PTM), Phthorimaea operculella Z., (Lepidoptera: Gelechiidae) is one of the serious worldwide pest of potato (Solanum tuberosum L. Solanaceae), this pest by making irregular tunnel leaves excreta behind and leads to a considerable yield loss (Herman et al., 2005). It causes serious damage to potato crops in fields and storage (Arnone et al., 1998). Presence of PTM in storage causing yield losses up to 100\% (Joshi, 1989 and Rondon, 2010).

Many different countries search for less dangerous pesticides by using the naturally occurring herbs that can be applied effectively in habitats (Rawi et al., 1995, 1996 and Sadek, 2003).

The current aims were conducted to study the role of certain Bacillus thuringiensis (B.t.) isolate and Artemisia judaica, plant extract as a biological control agent against Phthorimaea operculella.

\section{MATERIALS AND METHODS}

\section{Tested Insect}

The original colony of potato tuber moth (PTM) (Phthorimaea operculella, Gelechiidae; Lepidoptera) was supplied from the Plant Protection Research Institute, Agricultural Research Centre, Giza, 
Egypt. Mass rearing was carried out in the laboratory of the Economic Entomology Unit, Department of Plant Protection, Desert Research Center.

The infested potato tubers, containing different immature stages, were kept in glass jars $(20 \times 10 \mathrm{~cm})$ with fine layer about $3-4 \mathrm{~cm}$ of clean, sterilized sand and fresh potato tubers in each jar, for the completion of the development of the immature stages, and covered with a piece of cotton cloth and held by rubber band. Pupae were collected every 48 hours by sieving the sand layer. Collected pupae were kept in glass tubers $(3 \times 10 \mathrm{~cm})$ and covered with pieces of cotton cloth till emergence of moths. Emerged adults were collected by an aspirator and confined in an oviposition cage. The oviposition cage consisted of a glass jar ( $30 \mathrm{~cm}$ height $\times 25 \mathrm{~cm}$ diameter $)$ and covered by a piece of cloth (Dapalan), fixed on the top of the cage and held by rubber band to serve as oviposition sites. Within each cage, a piece of cotton moistened with $20 \%$ sugar solution was used for moth feeding, held by rubber band inside the cage and changed daily. The cotton cloth containing the eggs were removed daily and replaced by another clean one. The egg sheets were inserted in $2 \%$ sodium hypochlorite and fresh water, respectively, and then were dried well for 1-3 hours and kept in clean Petri dishes $(12 \mathrm{~cm})$.

\section{Soil Samples}

Soil samples were collected randomly from different fields in ElBahariya Oases. Surface materials of the soil was removed; and with a sterile spatula, about $100 \mathrm{~g}$ sample of soil was taken from at least $5 \mathrm{~cm}$ in depth. The soil samples were preserved in sterile plastic bags and stored for 2-12 months at $4{ }^{\circ} \mathrm{C}$ until analyzed. The collection sites had no history of treatment with B.t.

\section{Bacillus thuringiensis (B.t.) Isolation Technique}

Based on the acetate selective method described by Smith and Couche (1991), soil samples $(0.5 \mathrm{~g})$ were added, each to $10 \mathrm{ml}$ of LB broth buffered medium with $0.25 \mathrm{M}$ sodium acetate buffer at $\mathrm{pH} 6.8$ in a sterile conical flask under aseptic conditions in a laminar flow workstation. The flask was incubated in a controlled environment incubator shaker, Edmund Bühler (TH25) operated at $300 \mathrm{rpm}$ and $30^{\circ} \mathrm{C}$ for four hours. In this method, germination of B.t. spores was selectively inhibited by sodium acetate buffer $(0.25 \mathrm{M})$, while most of the undesired spore-formers germinated. Then, suspensions were allowed to stand for 10 minutes; the upper layer of suspended samples were transferred to a sterile test tube with screw cap, followed by heat treatment at $80^{\circ} \mathrm{C}$ for three minutes in a water bath. Heat treatment was made to eliminate all vegetative cells and non-sporulated soil microorganisms present in the samples. The samples were left to cool at room temperature before inoculating $1 \mathrm{ml}$ of the supernatant, using sterile pipettes onto agar plates and distributed over agar surface homogeneously. The plates were incubated overnight at $30^{\circ} \mathrm{C}$; then random colonies of B.t. from agar 
plates were transferred onto T3 - plates using sterile loop. Transferred colonies were left for 2-3 days at least to allow complete sporulation and crystal formation characteristic for B.t. isolate. Careful aseptic techniques were done for investigating the germinated colonies using a laminar flow workstation. Examination of germinated colonies was done using stained smears method. The germinated colonies were fixed to clean slides and stained according to Smirnoff (1962) stain method. For culturing the obtained isolates, the method Shake Flask Fermentation described by Morris et al. (1996). Small quantities of B.t. can easily be recovered by the lactose-acetone co-precipitation procedure of Dulmage et al. (1970), determining the number of bacteria that are present in the isolates described by Dulmage (1971), the total number of bacteria in the original solution was determined by counting the number of colony forming units (CFU's) and comparing them to the dilution factor. After that, serial dilutions from the original bacterial suspension were obtained. Tube 1 containing $4.5 \mathrm{ml}$ of water; in addition to $0.5 \mathrm{ml}$ of the undiluted bacterial suspension to yield a total volume of $5.0 \mathrm{ml}$.

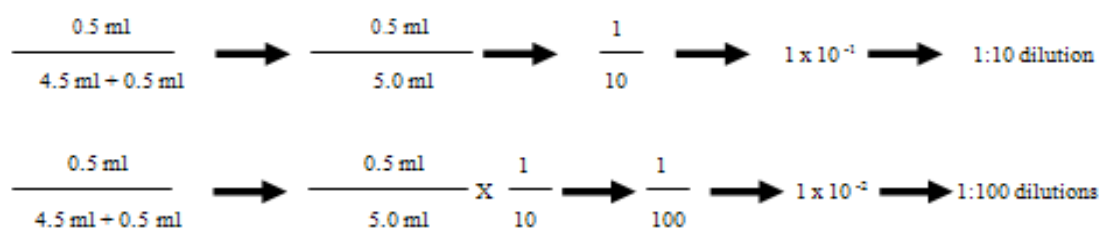

For each dilution, the number of colony forming units (CFU's) on the plates was counted. Typically, numbers between 30 and 800 are considered to be in the range of statistically accurate data. To calculate the number of bacteria per $\mathrm{ml}$ of diluted sample, the following equation was used:

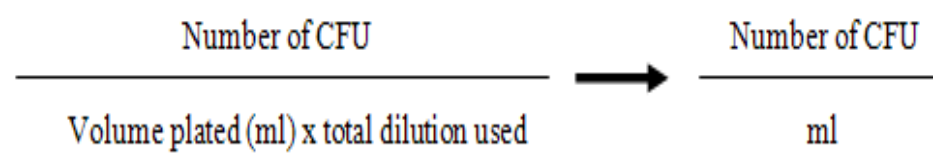

\section{Plant Materials}

Samples of Artemisia judaica were collected from three different regions (Elmejrh, Alhubaiqah and Ras Saada) in Nuweiba Desert region, South Sinai, Egypt, during September and November, 2016.

\section{Preparation of Plant Extracts}

A known weight of the powdered plant material (about $20 \mathrm{~g}$ ) was packed in a containers of glass separately and socked in $200 \mathrm{ml}$ of the solvent $(95 \%$ ethyl alcohol) for 7 days and shook for 15 minutes every day using an electric shaker. The alcoholic extracts were collected and then evaporated under vacuum at a temperature not exceeding $30^{\circ} \mathrm{C}$ in a rotary evaporator. The 
residue left after evaporation was used for biological tests (Yazdani et al., 2014). The concentrations used for treatment of pink bollworm were 100, 200, 400 and $800 \mathrm{ppm}$.

\section{Toxicity Test on Larval Stage \\ 6.1. Using B.t. isolate}

Larvae of Ph. operculella (after 5 days from egg hatching) were fed on thin slices of potato tuber, which were dipped in several concentrations of isolates $(1.25,2.5,5$, and $10 \mathrm{CFU} / \mathrm{ml})$. Control slices were dipped in water. After drying at room temperature, a single segment was placed in a Petri- dish $(10 \mathrm{~cm}$ diameter $)$ and ten starved larvae (for two hours) were introduced. The dish was then covered. For each concentration, 10 replicates of 10 larvae each were tested. Numbers of alive and dead larvae were recorded daily till pupation.

\subsection{Using $A$. judaica extract}

The same way of treatment was applied by using different concentrations of extracts $(125,250,500$ and $1000 \mathrm{ppm})$.

\section{Statistical Analysis}

Data obtained in different tests were subjected to statistical analysis to evaluate the relative efficiency of the isolates. Mortalities were corrected for the natural mortality according to Abbott's formula (1925).

The corrected percent $=($ Observed \%-Control \%) x 100/ $(100$-Control \% $)$

Concentration/mortality regression lines were drawn on probit logarithmic graph according to the method developed by Finney (1971). The $\mathrm{LC}_{50}$ and $\mathrm{LC}_{90}$ values were calculated according to probane program.

\section{RESULTS AND DISCUSSION}

\section{Toxic Effect of B.t. Isolate on Potato Tuber Moth Larvae}

Feeding of the larvae of Ph. operculella (Table 1) revealed adverse effects on the total percentage of larval mortality, which was concentration dependent. Whereas the total larval death recorded $6 \%$ in control trials, treatment revealed 14 and $58 \%$ of larval death at 1.25 and 10 $\mathrm{CFU} / \mathrm{ml}$, respectively. At any of the tested concentrations, the highest percentage of mortality occurred within the first three days following application, then the larval mortality started to decrease. As, for example, at 5 $\mathrm{CFU} / \mathrm{ml}$, the larval mortality started by $4 \%$ after the first day of treatment then recorded 6, 24, 4 and 4\% during days, respectively. 
Table (1). Toxic effect of B.t. isolate on Ph. operculella larvae.

\begin{tabular}{|c|c|c|c|c|c|c|c|c|c|c|c|c|}
\hline \multirow{3}{*}{$\begin{array}{c}\text { Conc. } \\
\text { (CFU/ml) }\end{array}$} & \multicolumn{10}{|c|}{ Mortality \% after indicated days } & \multirow{2}{*}{\multicolumn{2}{|c|}{$\begin{array}{c}\text { Total } \\
\text { mortality \% }\end{array}$}} \\
\hline & & & & & & & & & & & & \\
\hline & 1 & 2 & 3 & 4 & 5 & 6 & 7 & 8 & 9 & 10 & Obs. & Corr. \\
\hline 0.00 & 0 & 2 & 0 & 0 & 0 & 2 & 0 & 1 & 1 & 0 & 6 & 0.0 \\
\hline 1.25 & 0 & 4 & 6 & 0 & 0 & 0 & 0 & 4 & 0 & 0 & 14 & 8.2 \\
\hline 2.50 & 2 & 4 & 14 & 2 & 0 & 2 & 0 & 0 & 0 & 2 & 26 & 20.6 \\
\hline 5.00 & 4 & 6 & 24 & 4 & 0 & 2 & 0 & 0 & 2 & 0 & 42 & 37.0 \\
\hline 10.00 & 8 & 10 & 30 & 6 & 0 & 2 & 0 & 0 & 0 & 2 & 58 & 53.6 \\
\hline
\end{tabular}

The effect of B.t. isolate on PTM could be detected on the basis of the calculated $\mathrm{LC}_{50}$ and $\mathrm{LC}_{90}$ values, which recorded 7.95 and $48.00 \mathrm{CFU} / \mathrm{ml}$, respectively (Fig. 1).

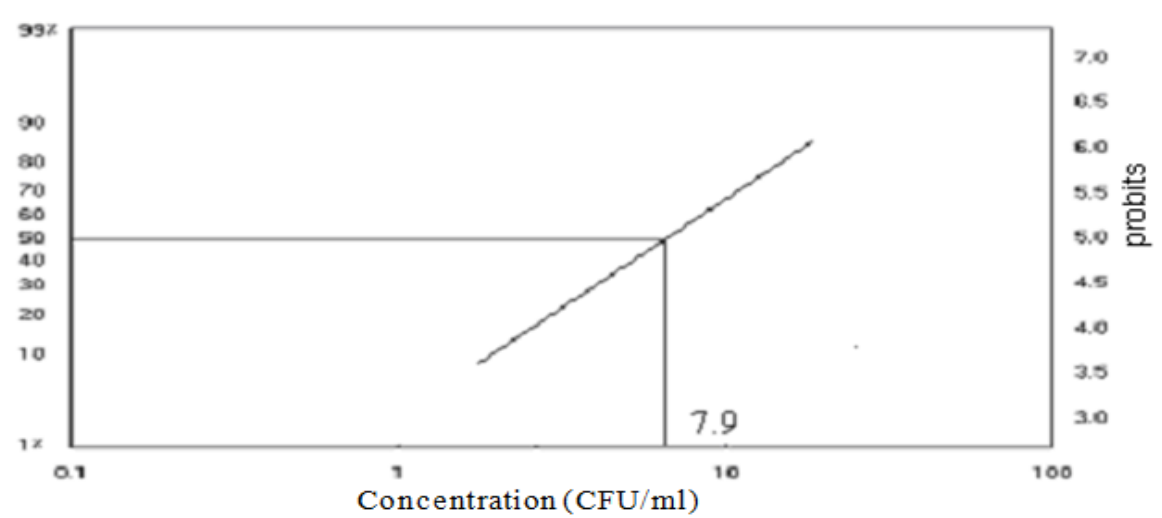

Fig. (1). Concentration / mortality regression lines for Ph. operculella larvae treated with B.t. isolate.

Larval mortality, according to Yoshinori and Kaya (1993), is probably due to either the septicemia in which the bacterial spores invade the hemocoel, multiply, produce toxin and subsequently kill the insect; or due to the toxemia in which the bacteria produce toxin and confined to the gut lumen. Abdel-Aziz (2000) attributed the larval mortality to such septicemia case. Mortality in infected larvae may also be due to the deficiency in the excretory system, due to Malpighian tubules infection (Lotfy, 1988). These factors individually or together may explain larval mortality.

The high percentage of larval mortality, three days post treatment, revealed higher susceptibility level of early larval instars of Ph. operculella to different concentrations of B.t. isolates. The higher susceptibility of young larval instars may be either due to the binding of the bacterial endotoxin to the brush border membrane of the midgut epithelium (Van Rie et al., 1990) or due 
to certain physiological differences between the early and late instars, where in late instars certain enzymes are secreted due to which tolerance to the bacterial infection may be developed (Goldberg et al., 1974). Such results are in harmony with Desuky (1998), who found that when the $2^{\text {nd }}$ larval instar of the cotton leaf worm was fed on both clover and cotton leaves, accumulative mortality percentage increased by time elapsed after spraying by Delfin till 24 hours, then decreased, whereas in case of the $4^{\text {th }}$ larval instar, the accumulative mortality percentage decreased.

\section{Toxic Effect of $\boldsymbol{A}$. judaica Extract on Potato Tuber Moth Larvae}

Exposure of potato tuber moth larvae to plant extract procedure revealed adverse effects on the total percent of larval mortality, which was concentration dependent. Increase in larval mortality was recorded at 125 to $1000 \mathrm{ppm}$ by 34 and $76 \%$, respectively. The data show that, the action of $A$. judaica active ingredient exerted cased the drastic larval death in the first and second days, after that the mortality decreased (Table 2).

Table (2). Toxic effect of A. judaica extract on Ph. operculella larvae.

\begin{tabular}{|c|c|c|c|c|c|c|c|c|c|c|c|c|}
\hline \multirow{3}{*}{$\begin{array}{l}\text { Conc. } \\
\text { (ppm) }\end{array}$} & \multicolumn{10}{|c|}{ Mortality $\%$ after indicated days } & \multirow{2}{*}{\multicolumn{2}{|c|}{$\begin{array}{c}\text { Total } \\
\text { mortality \% }\end{array}$}} \\
\hline & \multirow{2}{*}{1} & \multirow{2}{*}{2} & \multirow{2}{*}{3} & \multirow{2}{*}{4} & \multirow{2}{*}{5} & \multirow{2}{*}{6} & \multirow{2}{*}{7} & \multirow{2}{*}{8} & & \multirow{2}{*}{10} & & \\
\hline & & & & & & & & & & & Obs. & $\overline{\mathrm{Co}}$ \\
\hline 0 & . & 2 & & 0 & . & & 0 & - & 1 & 0 & 6 & 0 \\
\hline 125 & 16 & 8 & . & 0 & 2 & . & 2 & & 0 & 0 & 34 & 28.8 \\
\hline 250 & 24 & 8 & & 0 & 2 & 0 & 2 & 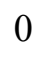 & 2 & 0 & 4 & 35.0 \\
\hline 500 & 30 & 12 & 0 & s & 4 & 2 & 0 & 0 & 2 & 0 & 58 & 53.6 \\
\hline 1000 & 46 & 12 & 6 & 4 & 4 & 2 & 0 & 2 & 0 & 0 & 76 & 72.2 \\
\hline
\end{tabular}

The effect of $A$. judaica extract on PTM could be detected on the basis of the calculated $\mathrm{LC}_{50}$ and $\mathrm{LC}_{90}$ values, which recorded 3.70 and $33.21 \mathrm{ppm}$, respectively (Fig. 2). 


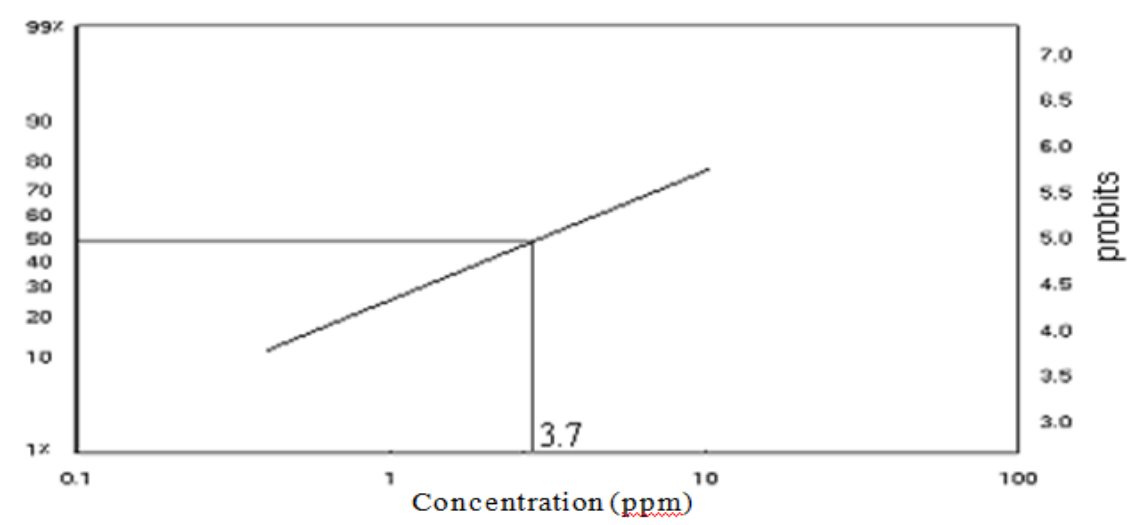

Fig. (2). Concentration/mortality regression lines for $P h$. operculella larvae treated with $A$. judaica extract.

Mohamed and Abdelgaleil (2008) found that, the essential oils of $A$. judaica showed the highest activity with Mentha microphylla. Abdelgaleil et al. (2008) mentioned that, the essential oil of $A$. judaica, grown on Sinai Peninsula of Egypt, was extracted via hydrodistillation. Chromatographic separation on repeated silica gel columns led to isolate two compounds namely piperitone and trans-ethyl cinnamate. Insecticidal, antifeedant and antifungal properties of the isolated compounds were examined. Both compounds showed pronounced insecticidal and antifeedant activity against the third instar larvae of Spodoptera littoralis (Boisd). The insecticidal potency of Artemisia spp. extracts of other tested plants can be attributed to several factors, including plant specific differences of the extracted active ingredients, types of the extracted products, differences in their mode of action, method of penetrations and the behavioral characteristics of the studied pests (Schmutterer, 1990 and Roger et al., 1995). It is now well established that in many plants including the tested plants especially Artemisia spp., the activity is due to the presence of saponin (Rawi et al., 1996), triterpenoid (Schmutterer, 1988) and alkaloids components (Kogam, 1986). Tannins compounds (Klock and Chan, 1986) effect seems to be very specific dependent.

As shown in this study, the effect of $A$. judaica extract on $P h$. operculella larval instar was more effective than the effect of $B$.t. isolate on the insect larvae. In order to get the best results when using the two bio-control agents in IPM strategies, the bacteria should be used first and then the plant extract.

The antibacterial properties of artemisinin had been tested on a wide range of bacteria (Sack, 1975), Staphylococcus aureus, Pseudomonas aeruginosa and Mycobacterium intracellulare (Slade et al., 2009). Meyer and Afolayan (1995) and Ibrahim et al. (2011) found that, artemisinin and its precursor were effective against gram-positive bacteria, and their antibacterial 
activities were similar to that of streptomycin, a bactericidal antibiotic. Artemisinin derived from field grown Artemisia annua plants was also reported to have antimicrobial activity (Ross et al., 2005 and Crespo-Ortiz and Wei, 2012). The susceptibility activity of gram-positive strains to artemisinin and precursor derived from in vitro A. annua plantlets, which had not been reported before confirmed that the in vitro plantlets could produce bioactive compounds that were similar to that found in the field grown mature plants of A. апnиа. These artemisinin and precursor produced from the in vitro plantlets also possess antimicrobial activity comparable to streptomycin.

\section{REFERENCES}

Abbott, W.S. (1925). A method of computing the effectiveness of an insecticide. Jour. Econ. Entomol., 18: 265.

Abdel-Aziz, S. Hanan (2000). Physiopathological studies on bacterial infection of cotton leaf worm, Spodoptera littoralis. M.Sc. Thesis, Fac. Sci., Ain Shams Univ., Egypt.

Abd-Elhady, H.K. (2012). Insecticidal activity and chemical composition of essential oil from Artemisia judaica L. against Callosobruchus maculatus (F.) (Coleoptera: Bruchidae). Journal of Plant Protection Research, 52 (3): 347-352.

Aggarwal, K.K., A.K. Tripathi, V. Prajapati and S. Kumar (2001). Toxicity of 1,8-cineol towards three species of stored product coleopterans. International Journal of Tropical Insect Science, 21 (2): 155-160.

Anshul, N., M. Srivastava and D. Singh (2015). Histopathological effects of Artemisia annua extract on the midgut of Helicoverpa armigera Hübner larvae (Lepidoptera: Noctuidae). Journal of Entomological Research, 39 (1): 5-8.

Arnone, S., S. Musmeci, L. Bacchetta, N. Cordischi, E. Pucci, M. Cristofaro and A. Sonino (1998). Research in Solanum spp. as sources of resistance to the potato tuber moth Phthorimaea operculella (Zeller). Potato Research, 41: 39-49.

Crespo-Ortiz, M.P. and M.Q. Wei (2012). Antitumor activity of artemisinin and its derivatives: from a well-known antimalarial agent to a potential anticancer drug. Journal of Biomedicine and Biotechnology, Article ID 247597, 18 p.

Desuky, H.M.W. (1998). Susceptibility of Spodoptera littoralis larvae to the microbial insecticide Delfin in the cotton and clover fields. J. Appl. Sci., 13 (1): 242-249.

Dulmage, H.T. (1971). Insecticidal activity of HD-1, a new isolate of Bacillus thuringiensis var. alesti. J. Invertebr. Pathol., 15: 232-239.

Dulmage, H.T., J.A. Correa and A.J. Martinez (1970). Co-precipitation with lactose as means of recovering the spore-crystal complex of Bacillus thuringiensis. J. Invertebr. Pathol., 18: 353-360. 
Durasula, A.N., A.M. Heimpel and T.A. Angus (1997). The site of action of crystalliferous bacteria in Lepidoptera larvae. J. Insect Pathol., 1: 152170.

Farag, N.A. (2002). Effect of Haphyllum tuberculatum extracts on an insect pest Spodoptera littoralis and the predator, Coccinella undecimpunctata. Ann. Agric. Sci. Cairo, 47: 1097-1105.

Finney, C.E. (1971). Probit analysis, a statistical treatment of the sigmoid response curve $7^{\text {th }}$ Ed. Cambridge Univ. Press, Cambridge, England FEMS Microbial. Lett., 231: 45-52.

Ross, G.S.A., M. Jacob and M.A. ElSohly (2005). Antifungal activity of artemisinin derivatives. Journal of Natural Products, 68 (8): 12741276.

Garczynski, U.J. and Y. Endo (1991). Mode of action of Bacillus thuringiensis endotoxin: General characteristics of intoxicated Bombyx larvae. J. Invertebr. Pathol., 35: 219-228.

Goldberg, L.J., I. Ford and S. Singer (1974). Bacillus thuringiensis var. fusiformis as a potential pathogen against Culex trasalis and Culex pipiens. Cal. Mosq. Cont. Assoc., 42: 81-82.

Haghighian, F., J. Sendi, A. Aliakbar and M. Javaherdashti (2008). The growth regulatory, deterrency and ovicidal activity of worm wood (Artemisia annua L.) on Tribolium confusum Duv. and identification of its chemical constituents by GCMS. Pestycydy, 12 (1-2): 51-59.

Hasheminia, S.M., J. Sendi, K.T. Jahromi and S. Moharrramipour (2011). The effect of Artemisia annua L. and Achillea millefolium L. crude leaf extracts on the oxicity, development, feeding efficiency and chemical activities of small cabbage Pieris rapae L. (Lepidoptera: Pieridae). Pesticide Biochemistry and Physiology, 99 (3): 244-249.

Herman, T.J.B., J.R. Clearwatwe and C.M. Triggs (2005). Impact of pheromone trap design, placement and pheromone blend on catch of potato tuber moth. New Zealand Plant Protection, 58: 219-223.

Ibrahim, G., U.O. Odunze and A. Muhammad (2011). Phytochemical and antimicrobial studies on Veronia blumedoides Hook Fil. (Asteraceae) ethanol extract. Nigerian Journal Pharmacy Science, 10: 50-56.

Joshi, S.L. (1989). Comparative life cycle of the Potatotuber moth, Phthorimaea operculella Zell. (Lepidoptera: Gelechiidae) on potato tubers and foliage and its economic loss yield. Journal of Entomological Society of Nepal, 1: 59-69.

Khosravi, R. and J. Sendi (2013). Toxicity, development and physiological effect of Thymus vulgaris and Lavandula angustifolia essential oils on Xanthogaleruca luteola (Coleoptera: Chrysomelidae). Journal of King Saud University Science, 25 (4): 349-355.

Klock, J.A. and B. Chan (1986). In: 'Chemistry and Technology of Agrochemical Formulations". Kluwer Academic Published Dordrecht, Boston, London.

Egyptian J. Desert Res., 69, No. 1, 87-99 (2019) 
Kogam, A. (1986). Natural chemicals in plant resistance to insect. Iowa state J. Res., 60: 501-527.

Lotfy, M. Nadia (1988). Pathogenesis of Bacillus thuringiensis toxic crystals in larvae of the silkworm, Bombyx mori. Ph.D. Thesis, Fac. Sci., Ain Shams Univ. Egypt.

Meyer, J.J.M. and A.J. Afolayan (1995). Antibacterial activity of Helichrysum aureonitens (Asteraceae). Journal of Ethnopharmacology, 47 (2): $109-111$.

Mohamed, M.I.E. and S.A.M. Abdelgaleil (2008). Chemical composition and insecticidal potential of essential oils from Egyptian plants against Sitophilus oryzae (L.) (Coleoptera: Curculionidae) and Tribolium castaneum (Herbst) (Coleoptera: Tenebrionidae). Applied Entomology and Zoology, 43 (4): 599-607.

Morris, O.N., M. Trottier, V. Converse and P. Kanagaratnam (1996). Toxicity of Bacillus thuringiensis subsp. aizawai for Mamestra configurata (Lepidoptera: Noctuidae). J. Econ. Entomol., 89 (2): 359-365.

Nakatani, M., S.A.M. Abd El-Galeil, J. Kurawaki, H. Okamura, T. Iwagawa and M. Doe (2002). Antifeedant ring B and D opened limonoids from Khaya senegalensis. J. Nat. Prod., 64: 1263-1265.

Rawi, S.M., H. El-Gindy, A.M. Haggag, A. Abou El Hassan, A. Abdel Kader (1995). Few possible molluscicides from calendula Micrantha officinalis and Ammi majus plants. I. Physiological effect on $B$. alexandrina and B. truncatus. J. Egypt. Ger. Soc. Zool., 16: 69-75.

Rawi, S.M., H. El-Gindy and A. Abd El-Kader (1996). New possible Molluscicides from Calendula micrantha officinalis and Ammi majus. II: Molluscicidal, physiological and egg laying capacity against $B$. alexandrina and B. truncates. J. Ecotoxicol. Environ. Saf., 35: 261267.

Roger, C., C. Vincent and D. Coderra (1995). Mortality and predation efficiency of Coleomegilla maculate lengi Timb. (Col., Coccinellidge) following application of neem extracts (Azadirachta indica A. Juss., Meliaceae). J. Appl. Ent., 119: 439-443.

Rondon, S.I. (2010). The potato tuberworm: a literature review of its biology, ecology, and control. Am. J. Pot. Res., 87: 149-166.

Sack, R.B. (1975). Human diarrheal disease caused by enterotoxigenic Escherichia coli. Annual Review of Microbiology, 29: 333-353.

Sadek, M.M. (2003). Antifeedant and toxic activity of Adhatoda vesica leaf extract against Spodoptera littoralis (Lep. Noctuidae). J. Appl. Entomol., 127: 396-404.

Abdelgaleil, S.A.M., M.A. Abbassyb, A.H. Belalb and Mona A.A. Abdel Rasoulb (2008). Bioactivity of two major constituents isolated from the essential oil of Artemisia judaica L. Bioresource Technology Journal, 99 (13): 5947-5950. 
Schmutterer, H. (1988). Potential of azadirachtin containing pesticides for integrated pest control in developing and industrialized countries. J. Ins. Phys., 34: 713-719.

Schmutterer, H. (1990). Properties and potential natural pesticides from the neem tree, Azadirachta indica. Ann. Rev. Ent., 35: 271-297.

Slade, D., A.M. Galal, W. Gul (2009). Antiprotozoal, anticancer and antimicrobial activities of dihydroartemisinin acetal dimers and monomers. Bioorganic and Medicinal Chemistry, 17 (23): 7949 7957.

Smirnoff, W.A. (1962). A staining method for differentiating spores, crystals and cells of Bacillus thuringiensis Berliner. J. Invertebr. Pathol., 4: 384-385.

Smith, R.A. and G.A. Couche (1991). The phylloplanc as a source of Bacillus thuringiensis variants. Applied and Environmental Microbiology, 57: 311-315.

Van Rie, J. W.H. McGaughey, D.E. Johnson, B.D. Barnett and H. Van Mellaert (1990). Mechanism of insect resistance to the microbial insecticide Bacillus thuringiensis. Sci., 247: 72-74.

Wang, N., H. Hong and H. Xu (1993). Observations on the histopathology of Pieris rapae infected with Bacillus thuringiensis. Chinese Journal of Biological Control, 3 (1): 27-29.

Yazdani, E., J. Jalali Sendi and J. Hajizadeh (2014). Effect of Thymus vulgaris L. and Origanum vulgare L. essential oils on toxicity, food consumption, and biochemical properties of lesser mulberry pyralid Glyphodes pyloalis Walker (Lepidoptera: Pyralidae). Journal of Plant Protection Research, 54 (1): 53-61.

Yoshinori, T. and H.K. Kaya (1993). Bacterial infections: Bacillaceae. In: "Insect Pathology." Published by Academic press INC, p. 83-146. 
دراسة التأثير السام لبكتريا باثليس ثيرونجينسيس ومستخلص نبات البعيثران )

إيمان إبراهيم إمام " وأسامة محمد أبو الغيط'

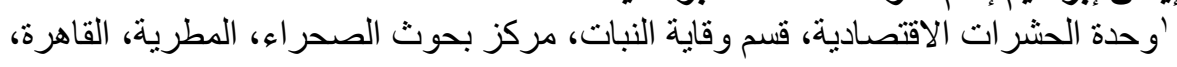
كوحدة الحشر ات الاقتصادية، قسم وقاية النبات، مركز بحوث الصحر اء، المطرية، القاهرة، مصر وكلية العلوم، جامعة جيزان، السعودية

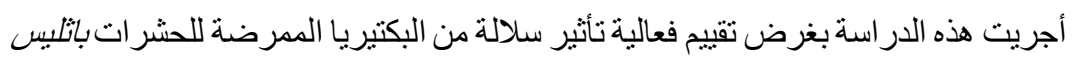

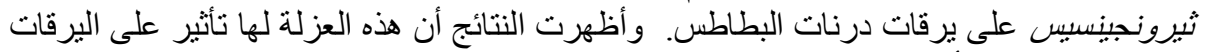

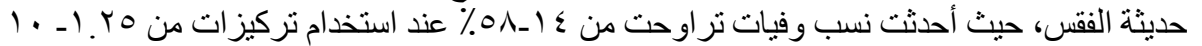

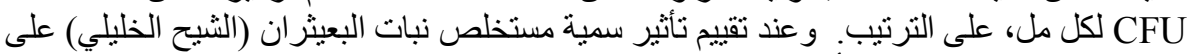

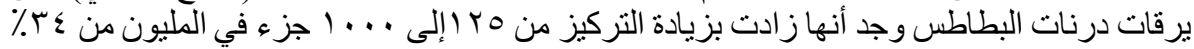

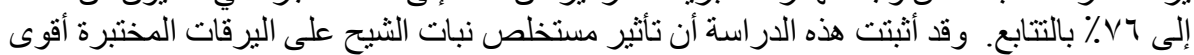

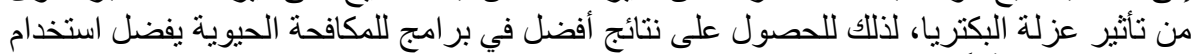

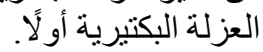

